\title{
Higher Education Quality Management
}

\author{
Elena V. Dokukina $\left.{ }^{1 *[O R C I D} 0000-0001-6160-7701\right]$, \\ Marina V. Samoshkina 1[ORCID 0000-0001-6383-1782], \\ Yury V. Daneykin 2[ORCID 0000-0001-7181-2557]
}

\author{
${ }^{1}$ LEONOV Moscow Region University of Technology, Korolev, Russia \\ ${ }^{2}$ Yaroslav-the-Wise Novgorod State University, Veliky Novgorod, Russia \\ dokukinaev@mail.ru
}

\begin{abstract}
The aim of the study is to analyze the prospects for managing the quality of higher education in the Russian Federation based on blended learning. To achieve this goal, the following tasks were performed: appropriate methods of analysis were selected, problems of the quality of higher education services were analyzed, breakthrough innovations in the field of higher education were considered, and problems of introducing blended learning models were assessed. Both the potential opportunities associated with the introduction of blended learning and the problems specific to Russian practice were considered. To carry out the analysis, the method of statistical analysis and the method of graphical analysis were applied in the work. The authors conclude that when implementing blended learning models in Russian higher education institutions, it is important to take into account a number of problems that may arise in practice including students' difficulties in doing homework systematically, the need to significantly increase the level of students' motivation, students' resistance to innovations that require them to be more involved, lack of knowledge in the field of information technology among educators, the resistance of certain groups of educators to changes that require the use of a new style of work, problems with the technical equipment of higher educational institutions, uneven development of Russian regions. At the same time, blended learning makes it possible to increase the availability of educational services and achieve a higher level of personalization of learning. The results obtained are of scientific importance because they contain conclusions regarding potential areas of quality management of higher education in the Russian Federation based on various models of blended learning.
\end{abstract}

Keywords: education quality, quality management, blended learning, digitalization, online learning, mastery learning

\section{INTRODUCTION}

The system of higher education in Russia is in a situation where it is increasingly influenced by fundamental socio-economic trends associated with the digitalization of the economy. Considering that digitalization is a process characteristic of most of the world's economies, the competitiveness and quality of the Russian higher education system are directly dependent on its compliance with modern technological and methodological standards.

The idea of education quality is the key and leading one when considering the development of a modern educational organization. The issues of introducing breakthrough educational innovations in
Russia have already been considered by a number of authors. Thus, N. Skrypnikova [1] evaluates the relevance of introducing blended learning models in the educational system of Russia and defines the task of introducing these models as a priority. B. Kireev [2] systematizes foreign and domestic experiments conducted to analyze the effectiveness of blended learning models. The author concludes that the use of blended learning models has a significant effect and contributes to the improvement of the quality of educational processes.

However, these researchers only covered primary and secondary education, while issues of blended learning in higher education have not been given sufficient attention. To bridge the gap within 
the framework of this study, the following research question has been posed: Is the task of introducing blended learning models relevant in managing the quality of higher education in Russia?

Further, the main problems of managing and improving the quality of higher education in Russia, which can be partially or completely solved through the introduction of digital technologies, as well as key concepts of the educational process that are most relevant in the digital economy, including blended learning, are considered.

\section{MATERIALS AND METHODS}

The purpose of the study is to explore the prospects for managing and improving the quality of higher education in Russia based on blended learning models. To achieve this goal, the following tasks have been performed: to select relevant methods of analysis, to identify problems of the quality of higher education in Russia, to systematize breakthrough innovations in the field of higher education, to consider the problems of introducing blended learning models into the educational process in Russian higher educational institutions.

The methodological apparatus includes statistical analysis and graphical analysis. With the help of statistical analysis, including methods and techniques used to collect and analyze original data, the key indicators that affect the quality of educational services have been analyzed.

The limitation of the study is related to the time frame covering 2017-2020.

\section{RESULTS}

One of the key problems of the quality of higher education in Russia, which is understood as the ability to form human capital through the use of a certain set of resources, is the limited resources.

Thus, in recent years there has been an increase in the workload of the faculty staff. Despite the fact that the number of students decreases during this period (from 4245.9 thousand people to 4068.0 thousand people), the number of faculty staff decreases even more (from 245.1 thousand people to 229.3 thousand people) (Figure 1) [3].

There is an increase in the ratio of the number of students to the number of faculty staff from 17.3 in the $2017 / 2018$ academic year to 17.7 in the 2019/2020 academic year.
The increasing workload of faculty members leads to a number of negative consequences for the productivity of higher education, including:

- reduction of the ability to apply an individual approach to learning;

- an increase in the risks of professional burnout of educators due to the high intensity of work;

- decrease in the level of control over the academic performance of students due to the reduction in the amount of resources available for this.

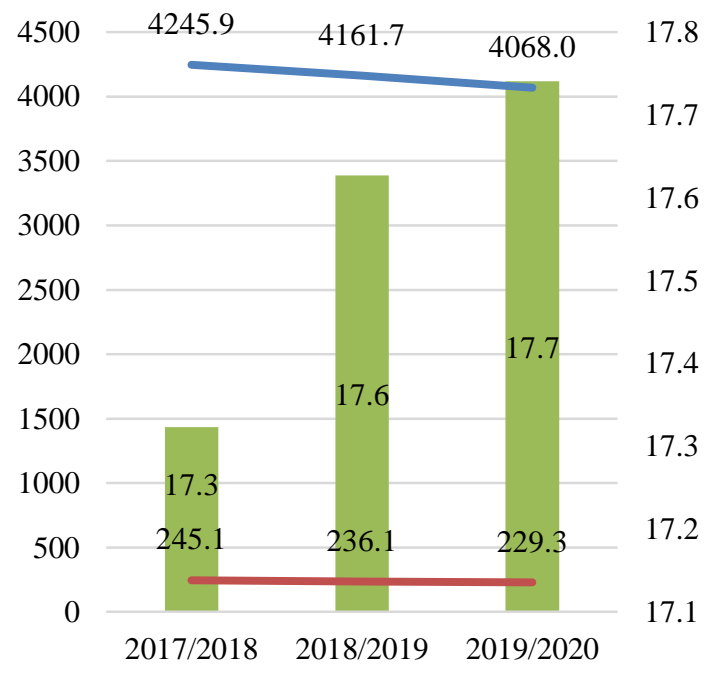

The ratio of the number of students to the number of faculty staff

Number of students, thousand people

Number of faculty staff, thousand people

Figure 1. Number of students and taculty statt in Russia, thousand people Source: [3]

The problem of increasing the workload of faculty members is particularly relevant in the context of increasing the share of the adult population in Russia with higher education. For Russia, this figure is $40.3 \%$, which is a rather low figure compared to some developed countries (Figure 2).

Increasing this rate is difficult to implement in the medium term, given the limited financial resources available to the higher education system in Russia. Expenditure on education as a percentage of the country's GDP is only 4\% (Figure 3). 


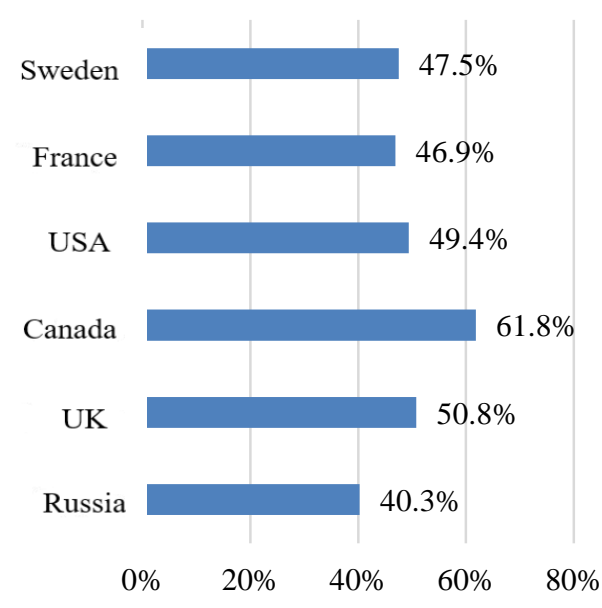

Figure 2. Share of adult population with higher education in its total population Source: [3]

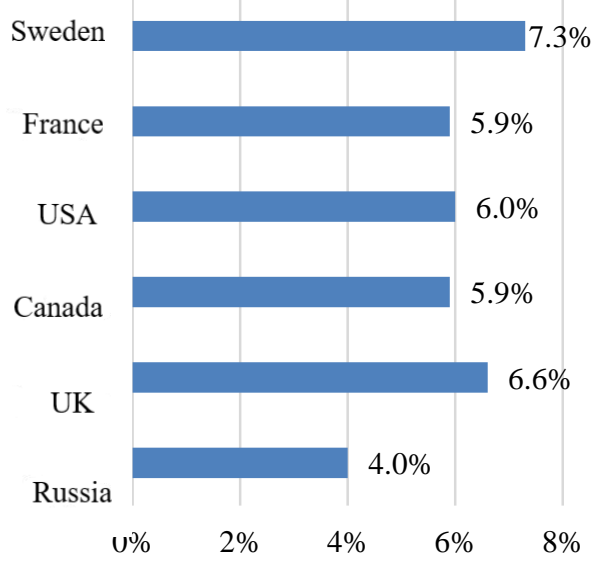

Figure 3. Education expenditures as a percentage of GDP by country

Source: [3]

Under these conditions, the task of increasing the productivity of higher education while increasing the availability of these services for a wider population is an urgent task. To accomplish this task, the advantages provided by the digitalization of educational services can be used.

Digitalization, which can be understood as the process of spreading the practice of using digital technologies in order to form new models of the pursuit of activities [4], has the potential to introduce breakthrough innovations in higher education.

A. Govindaraj and V.S.G. Silverajah [5] consider some blended learning models as a breakthrough innovation in education:

- Flex;

- A La Carte;

- Enriched virtual;
- Individual rotation.

These models imply a significant expansion of the role of online learning in the educational process.

Before considering in more detail the potential applications of these models in Russia, it is important to note that blended learning is based on the concept of mastery learning [6]. This concept implies that students must show mastery of a certain set of skills and knowledge before moving on to the next stage of learning. Thus, students need to fully master a certain part of the program in order to move further along the educational trajectory.

The concept of mastery learning has been developing since the 1920s. Modern research demonstrates that students who study under the programs of mastery learning show a higher level of academic performance compared to traditional training programs [7]. This effect is explained by the fact that students have fewer gaps in knowledge, so the rate of learning increases over time, as does the level of the mastery of learning.

P.I. Pietersen, C.B. Laursen, R.H. Petersen, and L. Konge [8] distinguish four basic stages of the implementation of the concept of mastery learning (Figure 4):

- obtaining theoretical knowledge and subsequent testing;

- acquiring applied knowledge with the help of an educator;

- self-training on a simulator;

- final test with a pre-defined pass/fail standard.

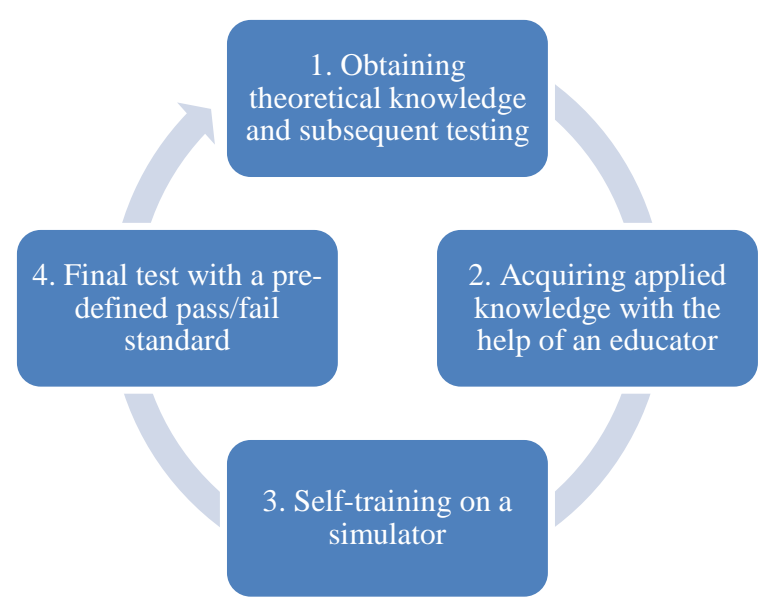

Figure 4. Basic stages of the implementation of the concept of mastery learning

Source: [8] 
An important feature of the concept of mastery learning is that the pace of learning is not set from the outside (for example, by an educator on the basis of drawing up a general schedule of classes), but is individual. Thus, the concept of mastery learning is based on the premise that students have significant differences in the pace of learning. This pace depends on the following basic factors:

- uneven distribution of initial knowledge among different students;

- individual cognitive predispositions to process various types of information;

- differences in personal motivation among different students;

- differences in the amount of free time among students, which is especially important for full-time/part-time study mode students, as well as senior students of bachelor's and master's programs.

To implement the concept of mastery learning, additional resources are needed to ensure the required level of control over student performance. These resources cannot be provided in today's Russian environment, as previously identified. On the contrary, there is an increase in the workload of the faculty staff.

In Russia, the Flipped Classroom model is the most widespread, according to which the learning of theoretical material is carried out on the basis of online learning, and practical tasks are performed in person together with the educator.

In particular, this technique is used at Kozma Minin Nizhny Novgorod State Pedagogical University [10], Vladivostok State University of Economics and Service [11], as well as in a number of private schools (this approach is especially widely used when teaching foreign languages).

Despite the fact that many Russian higher education institutions are making attempts to introduce blended learning models into the educational process, there are certain problems that limit the prospects for their application.

So, N. Tikhonova [12] identifies the following problems:

- difficulties of students in the systematic completion of homework;

- the need to significantly increase the level of motivation among students;

- resistance of students to innovations that require increased involvement from them;

- lack of knowledge in the field of information technology among educators;

- resistance of certain groups of educators to changes that require the use of a new style of work;

- problems with the technical equipment of higher educational institutions.

It is also important to note the problem of uneven development of Russian regions. To ensure the quality management of educational services in the format of online learning, a sufficiently high infrastructure development is necessary. In particular, stable access to high-speed Internet plays an important role.

\section{DISCUSSION}

Existing studies come to the conclusion that blended learning is a breakthrough innovation which is based on the idea of increasing the efficiency of the educational process when jointly using online learning and contact learning due to a higher level of personalization and expanding access to educational services [9]. In particular, blended learning allows you to build individual educational trajectories, meeting the needs of students with an advanced level of knowledge, as well as helping students fill in gaps in their knowledge.

However, most researchers consider the prospects and practice of applying blended learning at the level of primary school and secondary education. This study attempts to show the relevance of the application of blended learning models in higher education.

Theoretical models and practical examples show that blended learning can significantly improve the quality of educational services in the Russian higher education system. Thus, the issues of introducing blended learning in the quality management of higher education are relevant and priority.

\section{CONCLUSION}

The modern system of higher education in Russia is in a situation where a breakthrough innovation becomes both a serious challenge for the system and an opportunity for its improvement. Such an innovation, in our opinion, is blended learning, which is based on the joint use of online learning and contact learning to increase the level of personalization and improve the quality of learning. 
As a result of the study, the prospects for managing and improving the quality of higher education in Russia based on blended learning models have been studied. It has been concluded that the introduction of blended learning can increase the availability of educational services and make these services more personalized while scaling up the processes. To obtain the results of the study, the method of statistical analysis and the method of graphical analysis were applied, breakthrough innovations in the field of higher education were systematized, and the problems of introducing blended learning models into the educational process in Russian higher educational institutions were considered. It has been concluded that when introducing a blended learning model in the system of higher education in Russia, it is necessary to take into account the opportunities and potential problems that may arise in practice.

The results of the study are of practical importance, as they contain conclusions that can be useful for higher educational institutions in Russia that develop innovative teaching methods. Prospects for further research include quantifying the effect of the introduction of blended learning models in higher education institutions.

\section{AUTHORS' CONTRIBUTIONS}

Elena V. Dokukina, Yury V. Daneykin: general project management, the original drafting. Marina V. Samoshkina: analysis and adding information to the text of the article, collection and processing of materials.

\section{REFERENCES}

[1] N.N. Skrypnikova, "Blended learning technology: relevance and issues" [Tekhnologiya smeshannogo obucheniya: aktual'nost' i problematika], Vocational Education and Labour Market, 2018, vol. 3, pp. 74-78. (In Russ.).

[2] B.N. Kireev, "An overview on some results of the experiment on the use of blended learning in higher education institution", Prepodavatel XXI vek, 2018, vol. 3-1, pp. 48-60. (In Russ.).

[3] "Education in numbers: 2020: a brief statistical collection" [Obrazovaniye v tsifrakh: 2020: kratkiy statisticheskiy sbornik], L.M. Gokhberg, O.K. Ozerova, Ye.V. Sautina, N.B. Shugal, National Research University Higher School of Economics, Moscow: HSE University, 2020, 120 p. (In Russ.).
[4] J.C.G. dos Reis, M. Amorim, N. Melao, Yu. Cohen, "Digitalization: A literature review and research agenda", In Proceedings on $25^{\text {th }}$ International Joint Conference on Industrial Engineering and Operations Management, 2019, pp. 443-456. DOI: 10.1007/978-3-030-436162_47

[5] A. Govindaraj, V.S.G. Silverajah, "Blending Flipped Classroom and Station Rotation Models in Enhancing Students' Learning of Physics”, In Proceedings of the 2017 9th International Conference on Education Technology and Computers, 2017, pp. 73-78. DOI: $10.1145 / 3175536.3175543$

[6] S. Fatkhulloh, "Can blended learning replace conventional learning in terms of mastery learning and cognitive attainment", Journal of Physics: Conference Series, 2020, vol. 1511(1), p. $\quad 012025$. DOI: $10.1088 / 1742-$ 6596/1511/1/012025

[7] D. Davis, G. Chen, C. Hauff, G.-J. Houben, "Activating learning at scale: A review of innovations in online learning strategies", Computers \& Education, 2018, vol. 125, pp. 327-344.

DOI: 10.1016/j.compedu.2018.05.019

[8] P.I. Pietersen, C.B. Laursen, R.H. Petersen, L. Konge, "Structured and evidence-based training of technical skills in respiratory medicine and thoracic surgery", Journal of Thoracic Disease, 2021, vol. 13(3), pp. 20582067. DOI: $10.21037 /$ jtd.2019.02.39

[9] K.A. Jones, R.S. Sharma, "An experiment in blended learning: Higher education without lectures?", International Journal of Digital Enterprise Technology, 2019, vol. 1(3), pp. 241275. DOI: 10.1504/IJDET.2019.10019066

[10]L.I. Kutepova, V.L. Trostin, G.A. Leontyeva, "Experience in the educational process of mixed training technologies", Problems of Modern Pedagogical Education, 2018, vol. 60(3), pp. 186-189. (In Russ.).

[11]T.A. Borzova, "Teacher as a principle element of the "flipped classroom" technology", Higher Education in Russia, 2018, vol. 27(5), pp. 4249. (In Russ.).

[12]N.V. Tikhonova, "The "flipped classroom" method in higher education: opportunities and problems of implementation", Kazan Pedagogical Journal, 2018, vol. 2(127), pp. 7479. (In Russ.). 